\title{
Experimental evidence indicates that native freshwater fish outperform introduced Gambusia in mosquito suppression when water temperature is below $25^{\circ} \mathrm{C}$
}

\author{
Craig Lawrence $\cdot$ Neil Rutherford • \\ Rod Hamilton · Dean Meredith
}

Received: 1 July 2015/Revised: 14 August 2015/Accepted: 29 August 2015/Published online: 11 September 2015

(C) The Author(s) 2015. This article is published with open access at Springerlink.com

\begin{abstract}
In a series of laboratory trials, we compared the mosquito larvae predation efficacy of four endemic fish species and the introduced Gambusia holbrooki at different temperatures. Galaxias occidentalis and Galaxias truttaceus, consumed more mosquito larvae at 15 and $20^{\circ} \mathrm{C}$ and were equally effective consumers of mosquito larvae as G. holbrooki at $25^{\circ} \mathrm{C}$. Nannoperca vittata and Bostokia porosa were equally as effective at consuming mosquito larvae as $G$. holbrooki at 15,20 and $25^{\circ} \mathrm{C}$. G. occidentalis in particular warrant further investigation as a mosquito control agent, not only due to their high consumption of mosquito larvae, but also due to their propensity to kill, but not consume more mosquito larvae than the other four fish species at both 15 and $20^{\circ} \mathrm{C}$. For this species, stomach size and digestion rate do not appear to limit the number of mosquito larvae killed. These results indicate that
\end{abstract}

Handling editor: Alison King

C. Lawrence $(\bowtie) \cdot$ N. Rutherford · R. Hamilton .

D. Meredith

Department of Fisheries, Western Australian Fisheries and

Marine Research Laboratories, Hillarys, WA 6025,

Australia

e-mail: craig.lawrence@fish.wa.gov.au

C. Lawrence

School of Animal Biology and Institute of Agriculture, The University of Western Australia, Hackett Drive, Crawley, WA 6009, Australia endemic fish species may be more successful than the introduced G. holbrooki at mosquito control.

Keywords Mosquito - Predation · Fish - Gambusia . Galaxias · Nannoperca

\section{Introduction}

Despite a lack of research quantifying their effectiveness as a biological control agent for mosquitoes, in the early 1900s international health authorities and philanthropic organisations introduced Eastern Gambusia (Gambusia holbrooki Girard, 1859 Poeciliidae) or Western Gambusia (Gambusia affinis Baird \& Girard, 1853 Poeciliidae) to all continents except Antarctica (Courtenay \& Meffe, 1989; Lloyd, 1990). In 1934, without any prior evaluation of endemic fish species, G. holbrooki was introduced to Western Australia and distributed by the Public Health Department to prevent the spread of mosquito-borne disease (Mees, 1977). This species is now widespread throughout the southwest of the State (Morgan et al., 1998), particularly in urban areas where they are now found in $63 \%$ of natural waterbodies and most artificial lakes (Major, 2009; Hourston et al., 2014). G. holbrooki also has a colonizing life history (i.e. early maturation, high reproductive effort) that enables them to rapidly populate a waterbody (Macdonald \& Tonkin, 2008). This combined with their agonistic behaviour has contributed to the loss of 
endemic fish species (Myers, 1965; Coy, 1979; Gill et al., 1999) and has led to them now being the most abundant freshwater fish species on the Swan Coastal Plain, where they represent $79 \%$ of the total fish abundance in this region (Hourston et al., 2014). However, despite the wide distribution and abundance of Gambusia, in south-western Australia the incidence of mosquito-borne diseases such as Ross River virus, Barmah Forest virus, Murray Valley encephalitis virus and Kunjin virus has not decreased (Russell, 1998, 2002).

There is evidence to suggest that G. holbrooki are not effective at controlling mosquito larvae abundance (Blaustein, 1992). G. holbrooki, is a sub-tropical poeciliid originally from Georgia USA with a preferred temperature of $27^{\circ} \mathrm{C}$ (Coutant, 1977; Lloyd \& Tomasov, 1985). However, even in sub-tropical water temperatures $\left(25^{\circ} \mathrm{C}\right)$ one Australian endemic species, Crimson-spotted rainbowfish (Melanotaenia duboulayi Castelnau, 1878 Melanotaeniidae), has been shown to consume more mosquito larvae than $G$. holbrooki (Hurst et al., 2004). At the same temperature the predation rate of two other endemic species, Australian smelt (Retropinna semoni Weber, 1895 Retropinnadae) and Fly specked hardyhead (Craterocephalus stercusmuscarum Gunther, 1867 Atherinidae), is similar to that of G. holbrooki (Hurst et al., 2004).

In contrast south-western Australia has a temperate climate, so in this environment the impact of $G$. holbrooki upon mosquito larvae may be even further reduced due to their digestive and reproductive physiology. Firstly, at water temperatures below $30^{\circ} \mathrm{C}$ G. holbrooki's metabolic rate, and in particular food consumption and swimming speed (i.e. ability to capture prey), decrease exponentially (Wurtsbaugh \& Cech, 1983; Cech et al., 1985). Furthermore, their digestion rate also decreases with declining water temperature. Hence, the volume of their digestive tract and rate of discharge restricts the number of mosquito larvae they can consume at cooler water temperatures. For example, at $30^{\circ} \mathrm{C}$ complete discharge of mosquito larvae occurs $3-4 \mathrm{~h}$ after ingestion, but at $17-23^{\circ} \mathrm{C}$ complete discharge does not occur until 5-6 h after ingestion (Sokolov \& Chvaliova, 1936). Secondly, in temperate climates, G. holbrooki abundance decreases markedly during the cooler months, then rapidly increases after reproduction peaks in mid-summer (Melden, 1951; Brown \& Fox, 1966; Penn \& Potter,
1991). Consequently, G. holbrooki is typically only abundant at water temperatures above $20^{\circ} \mathrm{C}$ (Rowe et al., 2007). However, in south-western Australia mosquito larvae begin to hatch in spring, when water temperatures are around $10-15^{\circ} \mathrm{C}$, well before the peak in G. holbrooki reproduction occurs. Furthermore, aside from shallow, unshaded waterbodies, few freshwater habitats in south-western Australia reach water temperatures of $25-30^{\circ} \mathrm{C}$ or above, except for a brief period in the peak of summer.

For many years there have been anecdotal reports that endemic species from south-western Australia, in particular the Western Pygmy Perch (Nannoperca vittata Casltelnau, 1873 Nannopercidae), prey upon mosquito larvae (e.g. Coy, 1979). However, this claim has never been experimentally tested for any Western Australian species, let alone quantified to determine which species is the most effective mosquito larvae predator.

The aim of this experiment was to compare the relative mosquito larvae predation rates of four temperate endemic fish species from south-western Australia-Western Pygmy Perch (N. vittata), Western Minnow (Galaxias occidentalis Ogilby, 1899 Galaxiidae), Spotted Minnow (Galaxias truttaceus Valenciennes, 1846 Galaxiidae) and Nightfish (Bostokia porosa Castelnau, 1873 Percichthyidae)—with G. holbrooki in temperate $\left(15\right.$ and $\left.20^{\circ} \mathrm{C}\right)$ and tropical $\left(25^{\circ} \mathrm{C}\right)$ water temperatures.

\section{Materials and methods}

Collection and holding of freshwater fish

$N$. vittata (mean standard length and $\mathrm{SD}$ of $56 \pm 2.6 \mathrm{~mm}$, range $50-60 \mathrm{~mm}$; mean weight and $\mathrm{SD}$ of $3.78 \pm 0.46 \mathrm{~g}$, range $2.99-4.33 \mathrm{~g}$ ); G. occidentalis (mean standard length and SD of $51 \pm 4.9 \mathrm{~mm}$, range $47-62 \mathrm{~mm}$; mean weight and $\mathrm{SD}$ of $0.87 \pm 0.15 \mathrm{~g}$, range $0.73-1.15 \mathrm{~g}$ ); and $B$. porosa (mean standard length and SD of $69 \pm 3.7 \mathrm{~mm}$, range $65-75 \mathrm{~mm}$; mean weight and $\mathrm{SD}$ of $5.87 \pm 0.80 \mathrm{~g}$, range $5.22-7.19 \mathrm{~g}$ ) were collected from Helena River $\left(31^{\circ} 56^{\prime} \mathrm{S} 116^{\circ} 25^{\prime} \mathrm{E}\right)$ using double-winged and single-winged fyke nets. G. truttaceus (mean standard length and SD of $78 \pm 11.1 \mathrm{~mm}$, range $67-93 \mathrm{~mm}$; mean weight and $\mathrm{SD}$ of $5.25 \pm 2.28 \mathrm{~g}$, range $3.20-8.76 \mathrm{~g}$ ) were 
collected from Goodga River $\left(34^{\circ} 56^{\prime} \mathrm{S} 118^{\circ} 4^{\prime} \mathrm{E}\right)$ using A-Frame traps. G. holbrooki (mean standard length and SD of $29.3 \pm 1.8 \mathrm{~mm}$, range $27-32 \mathrm{~mm}$; mean weight and SD of $0.49 \pm 0.10 \mathrm{~g}$, range $0.38-0.62 \mathrm{~g}$ ) were collected from Herdsmans Lake $\left(31^{\circ} 55^{\prime} \mathrm{S}\right.$ $115^{\circ} 48^{\prime} \mathrm{E}$ ) using scoop nets and A-Frame traps.

Wild collected N. vittata, G. occidentalis, $G$. truttaceus, B. porosa and G. holbrooki were transported to The University of Western Australia Aquatic Research Laboratory, Perth in 2001 polyethylene insulated boxes (IceKool, Australia). Immediately upon arrival all fish were immersed in a salt bath $(5 \mathrm{~g} / \mathrm{l}$ of $\mathrm{NaCl})$ for $15 \mathrm{~min}$ to remove external pathogens. They were then placed into $10 \times 2001$ cylindrical tanks $(90 \mathrm{~cm}$ diameter $\times 52 \mathrm{~cm}$ high; two tanks for each species) each fitted with individual biological filters, UV water treatment and foam fractionators for a 30-day quarantine and acclimation period. During this period all fish were fed bloodworms (Hikari Sales, USA Inc.) a prey of similar body length (BL, mean $\pm \mathrm{SD}=8.78 \pm 1.02 \mathrm{~mm}$ ), body width (BW, mean $\pm \mathrm{SD}=0.66 \pm 0.20 \mathrm{~mm}$ ) and shape, to instar IV mosquito larvae (BL mean \pm $\mathrm{SD}=7.57 \pm 0.55 \mathrm{~mm}$, BW mean $\pm \mathrm{SD}=0.82 \pm$ $0.12 \mathrm{~mm}$ ). Each tank was maintained at $\mathrm{pH}=$ 7.0-7.4, a salinity of $0-2 \%$, dissolved oxygen $8-10 \mathrm{mg} / \mathrm{l}$, ammonia $<0.01 \mathrm{mg} / \mathrm{l}$ and a temperature of $16^{\circ} \mathrm{C}$. This ensured that the fish were feeding normally and acclimated to the tank environment prior to the commencement of the first $15^{\circ} \mathrm{C}$ mosquito larvae predation trials. At the conclusion of each temperature trial, fish were returned to the 10 conical tanks and the water temperature within these tanks was gradually increased over a period of 4-5 days to the next test temperature (i.e. to $20^{\circ} \mathrm{C}$, then $25^{\circ} \mathrm{C}$ ).

\section{Mosquito larvae}

Several serious human diseases including Murray Valley encephalitis virus, Kunjin virus, Barmah Forest virus and Ross River virus, the most common mosquito-borne pathogen in Australia, have all been isolated from the common urban mosquito Culex quinquefasciatus (Mackenzie et al., 1994; Russell, 1998). To produce sufficient $C$. quinquefasciatus larvae for this experiment $6 \times 12001$ tanks $(1.6 \mathrm{~m} \times 1.6 \mathrm{~m} \times 0.5 \mathrm{~m})$ were filled with water 3 months prior to commencing the first mosquito larvae predation trial. Eggs laid in the tanks by $C$. quinquefasciatus were hatched and larvae reared until the majority had reached instar IV.

Predation upon instar IV larvae was recorded in this study, (in preference to instars I-III), as a key attribute for effective piscivorous control of mosquito larvae is the consumption of later instars. This is because after instar IV the larvae become airborne, but up until this stage is subject to natural mortality that can be as high as $90 \%$ (McDonald \& Buchanan, 1981).

\section{Experimental design}

This study recorded mosquito larvae predation by five fish species at three temperatures $\left(15,20\right.$ and $\left.25^{\circ} \mathrm{C}\right)$. Each temperature trial had five replicates per fish species and five control tanks. The five control tanks contained only mosquito larvae to permit natural larval mortality to be recorded.

The laboratory methods used in this study were adapted from those detailed by Homski et al. (1994), Russell et al. (2001), Hurst et al. (2004) and Willems et al. (2005). In this study two 12001 water baths $(1.6 \mathrm{~m} \times 1.6 \mathrm{~m} \times 0.5 \mathrm{~m})$ were constructed and connected to a water heater-chiller (Fish Cooler DBA150, Daeil Cooler Co Ltd, Korea). Into this bath were placed $30 \times 101$ tanks each filled with 71 water from the fish-holding tank system. Thermometers were placed in the tanks and water temperature adjusted to either $15 \pm 0.2^{\circ} \mathrm{C}$, or $20 \pm 0.2^{\circ} \mathrm{C}$ or $25 \pm 0.2^{\circ} \mathrm{C}$ for $48 \mathrm{~h}$ before each trial commenced.

Five of each fish species were removed from the 2001 population holding tanks and placed (1 fish/tank) into one of 25 randomly selected 101 tanks for an acclimation period of $24 \mathrm{~h}$ before the commencement of each trial. They were not fed for the ensuing $24 \mathrm{~h}$ to standardise hunger levels. After the acclimation period a random sample of mosquito larvae was collected from the $6 \times 12001$ larvae culture tanks. The larvae were graded and hand sorted to remove any instar I, II or III larvae and nauplii. Instar IV larvae were then counted and 200 placed into each of the 25 treatment and five control 101 tanks (a total of 6000 larvae/trial). Lids were placed on each tank and left undisturbed for $24 \mathrm{~h}$ (12:12 h light:dark photoperiod). After $24 \mathrm{~h}$, fish were removed from their tanks. Each fish was anaesthetised (Aqui-S $5 \mathrm{mg} / \mathrm{l}$ ) for $15 \mathrm{~min}$ to enable individual standard length $( \pm 1.0 \mathrm{~mm})$ and wet weight ( $\pm 0.01 \mathrm{~g}$ ) to be recorded. Remaining mosquito larvae 
in each tank were counted, both dead and alive, and consumption, or in the case of the control tanks natural mortality, calculated.

\section{Statistical analyses}

To correct fish predation data for natural mosquito larvae mortality, Abbott's formula (Abbott, 1925) was used to normalise treatment data for each trial with respect to the mortality recorded in the control tanks. Data were then square root transformed to satisfy the assumptions of normality and equal variance. The Shapiro-Wilk test was used to verify the assumption of normality prior to ANOVA. Mosquito larvae predation rates among fish species for each temperature trial were tested by one-way ANOVA, with all pair-wise comparisons analysed post hoc by Fisher's Least Significant Difference test. (Stat Plus: Mac OS, version 2009, AnalystSoft Inc.).

\section{Results}

Fish consumption of fourth instar $C$.

quinquefasciatus larvae

The temperate endemic galaxiids (G. occidentalis and G. truttaceus) consumed more mosquito larvae at both $15^{\circ} \mathrm{C}(P=0.04)$ and $20^{\circ} \mathrm{C}(P=0.01)$ than $G$. holbrooki. Furthermore both endemic galaxiids were equally effective consumers of mosquito larvae compared to G. holbrooki at tropical temperatures $25^{\circ} \mathrm{C}$ $(P=0.49)$ (Table 1). N. vittata and B. porosa were equally as effective at consuming mosquito larvae as G. holbrooki at 15,20 and $25^{\circ} \mathrm{C}(P=0.49)$ (Table 1$)$.

Table 1 Mean number of fourth instar C. quinquefasciatus larvae (expressed as Abbots adjusted $( \pm \mathrm{SD}$ ) for natural mortality) consumed over $24 \mathrm{~h}$ by four native fish species and $G$. holbrooki at 15,20 and $25^{\circ} \mathrm{C}$

\begin{tabular}{lcrl}
\hline Fish species & $15^{\circ} \mathrm{C}$ & $20^{\circ} \mathrm{C}$ & $25^{\circ} \mathrm{C}$ \\
\hline G. occidentalis & $58.0^{\mathrm{a}}(52.1)$ & $73.9^{\mathrm{a}}(54.8)$ & $35.8^{\mathrm{a}}(44.1)$ \\
G. truttaceus & $25.9^{\mathrm{a}, \mathrm{b}}(29.8)$ & $82.1^{\mathrm{a}}(64.6)$ & $45.8^{\mathrm{a}}(64.7)$ \\
N. vittata & $7.9^{\mathrm{b}}(11.1)$ & $35.7^{\mathrm{b}, \mathrm{c}}(39.8)$ & $26.5^{\mathrm{a}}(23.3)$ \\
B. porosa & $2.4^{\mathrm{b}}(5.7)$ & $16.7^{\mathrm{c}}(28.9)$ & $14.2^{\mathrm{a}}(16.4)$ \\
G. holbrooki & $16.8^{\mathrm{b}}(9.3)$ & $34.7^{\mathrm{b}, \mathrm{c}}(17.6)$ & $43.1^{\mathrm{a}}(51.9)$ \\
\hline a,b,c Column means followed by the same letter were not &
\end{tabular}

Effect of fish size upon consumption of fourth instar of C. quinquefasciatus larvae

At $15^{\circ} \mathrm{C}$ G. occidentalis consumed more mosquito larvae per mm of its SL $(P=0.02)$ than $G$. truttaceus, $N$. vittata, B. porosa and G. holbrooki (Table 2). However, when water temperature increased to $20^{\circ} \mathrm{C}$ the difference among species diminished (although still significant $P=0.01$ ) due largely to increased consumption per $\mathrm{mm}$ SL by $N$. vittata and $G$. holbrooki. By $25^{\circ} \mathrm{C}$ all fish consumed similar numbers of mosquito larvae per mm SL $(P=0.07)$ (Table 2).

At $15^{\circ} \mathrm{C} \mathrm{G}$. occidentalis consumed more mosquito larvae per $\mathrm{g}$ bodyweight $(P=0.003)$ (Table 3$)$. At $20^{\circ} \mathrm{C}$ the difference in consumption/g body weight decreased between G. occidentalis and G. holbrooki $(P=0.40)$, but was still significant among species $(P<0.00)$. At $25^{\circ} \mathrm{C} \mathrm{G}$. holbrooki consumed more mosquito larvae/g than the other species $(P<0.05)$, but as shown by the large SD consumption was highly variable among individuals (Table 3 ).

Fish consumption versus predation of fourth instar C. quinquefasciatus larvae

The number of dead mosquito larvae in each tank at the conclusion of each trial showed that in addition to consuming large numbers of mosquito larvae, $G$. occidentalis killed, but did not consume, more mosquito larvae than the other four fish species both at $15^{\circ} \mathrm{C}(P=0.02)$ and $20^{\circ} \mathrm{C}(P<0.000)$ (Table 4$)$. At these temperatures there was no difference in the number of dead mosquito larvae from natural mortality (control) tanks or those containing the other four fish species (Table 4).

\section{Discussion}

The use of larvivorous fishes is one of the oldest methods for biological control of mosquito larvae populations. Despite this there are relatively few controlled studies comparing fishes predation efficiency at the range of temperatures at which mosquito larvae survive. While there are numerous studies on the use of fish to control mosquito larvae, in general the lack of a standardised approach limits comparison among fish species. The benefit of the experimental design in this study is that it permits direct comparison 
Table 2 Mean number of fourth instar C. quinquefasciatus larvae (expressed as Abbots adjusted ( \pm SD) for natural mortality) consumed per mm SL (Standard Length) over $24 \mathrm{~h}$ by four native fish species and G. holbrooki at 15,20 and $25^{\circ} \mathrm{C}$

\begin{tabular}{lllr}
\hline Fish species & $15^{\circ} \mathrm{C}$ & $20^{\circ} \mathrm{C}$ & $25^{\circ} \mathrm{C}$ \\
\hline G. occidentalis & $1.16^{\mathrm{a}}(1.00)$ & $1.43^{\mathrm{a}}(1.10)$ & $0.75^{\mathrm{a}}(0.42)$ \\
G. truttaceus & $0.34^{\mathrm{b}}(0.45)$ & $1.08^{\mathrm{a}, \mathrm{b}}(0.87)$ & $0.62^{\mathrm{a}}(0.94)$ \\
N. vittata & $0.14^{\mathrm{b}}(0.20)$ & $0.65^{\mathrm{a}, \mathrm{b}, \mathrm{c}}(0.73)$ & $0.48^{\mathrm{a}}(0.41)$ \\
B. porosa & $0.03^{\mathrm{b}}(0.20)$ & $0.25^{\mathrm{c}}(0.43)$ & $0.20^{\mathrm{a}}(0.24)$ \\
G. holbrooki & $0.57^{\mathrm{b}}(0.32)$ & $1.18^{\mathrm{a}}(0.61)$ & $1.44^{\mathrm{a}}(1.68)$ \\
\hline
\end{tabular}

a,b,c Column means followed by the same letter were not significantly different $(P>0.05)$

Table 3 Mean number of fourth instar $C$. quinquefasciatus larvae (expressed as Abbots adjusted ( \pm SD) for natural mortality) consumed per $\mathrm{g}$ of fish bodyweight over $24 \mathrm{~h}$ by four native fish species and G. holbrooki at 15,20 and $25^{\circ} \mathrm{C}$

\begin{tabular}{lcrr}
\hline Fish species & $15^{\circ} \mathrm{C}$ & $20^{\circ} \mathrm{C}$ & $25^{\circ} \mathrm{C}$ \\
\hline G. occidentalis & $67.45^{\mathrm{a}}(56.89)$ & $84.73^{\mathrm{a}}(60.52)$ & $39.25^{\mathrm{b}}(48.01)$ \\
G. truttaceus & $6.09^{\mathrm{b}}(9.61)$ & $18.61^{\mathrm{b}}(17.20)$ & $11.35^{\mathrm{b}}(19.34)$ \\
N. vittata & $1.93^{\mathrm{b}}(2.84)$ & $9.72^{\mathrm{b}}(11.35)$ & $7.58^{\mathrm{b}}(6.94)$ \\
B. porosa & $0.41^{\mathrm{b}}(1.01)$ & $3.07^{\mathrm{b}}(5.06)$ & $2.24^{\mathrm{b}}(2.74)$ \\
G. holbrooki & $34.00^{\mathrm{b}}(15.55)$ & $72.04^{\mathrm{a}}(39.15)$ & $92.97^{\mathrm{a}}(103.31)$
\end{tabular}

a,b Column means followed by the same letter were not significantly different $(P>0.05)$

Table 4 Mean number dead, but not consumed, of fourth instar C. quinquefasciatus predated upon over 24 h by four native fish species, G. holbrooki and control at 15,20 and $25^{\circ} \mathrm{C}$

\begin{tabular}{llll}
\hline Fish species & $\begin{array}{l}15^{\circ} \mathrm{C} \\
\text { Mean number dead } \\
\text { mosquito larvae }( \pm \mathrm{SD})\end{array}$ & $\begin{array}{l}20^{\circ} \mathrm{C} \\
\text { Mean number dead } \\
\text { mosquito larvae }( \pm \mathrm{SD})\end{array}$ & $\begin{array}{l}25^{\circ} \mathrm{C} \\
\text { Mean number dead } \\
\text { mosquito larvae }( \pm \mathrm{SD})\end{array}$ \\
\hline G. occidentalis & $22.60^{\mathrm{a}}(22.21)$ & $27.50^{\mathrm{a}}(31.93)$ & $3.10^{\mathrm{a}}(7.08)$ \\
G. truttaceus & $6.60^{\mathrm{b}}(5.08)$ & $3.40^{\mathrm{b}}(7.06)$ & $4.90^{\mathrm{a}}(11.11)$ \\
N. vittata & $0.00^{\mathrm{b}}(0.00)$ & $0.10^{\mathrm{b}}(0.32)$ & $0.10^{\mathrm{a}}(0.32)$ \\
B. porosa & $2.00^{\mathrm{b}}(2.83)$ & $0.80^{\mathrm{b}}(2.53)$ & $1.80^{\mathrm{a}}(2.94)$ \\
G. holbrooki & $2.80^{\mathrm{b}}(4.09)$ & $3.50^{\mathrm{b}}(3.89)$ & $9.30^{\mathrm{a}}(13.63)$ \\
Control & $2.00^{\mathrm{b}}(2.92)$ & $0.20^{\mathrm{b}}(0.63)$ & $1.60^{\mathrm{a}}(4.40)$ \\
\hline
\end{tabular}

a,b Column means followed by the same letter were not significantly different $(P>0.05)$

of mosquito larvae consumption among fish at $25^{\circ} \mathrm{C}$ from both northern and southern Australia. The consumption rate by $G$. holbrooki at $25^{\circ} \mathrm{C}(43.1$ Instar IV larvae/24 h) recorded in this study is similar to the 41.8 Instar IV larvae/24 h reported by Hurst et al. (2004) at the same temperature. The mean number/g body weight $( \pm \mathrm{SD})(92.97 \pm 103.31)$ consumed by $G$. holbrooki in this experiment was less than previously reported at $25^{\circ} \mathrm{C}(121 \pm 56.7)$ (Hurst et al., 2004), but this may be due to the high variation among individuals. Further research into the variation in mosquito larvae consumption among fishes at different temperatures, as undertaken in this study, will provide important information for the selection of fish species for stocking in sub-tropical and temperate environments to control mosquito-borne disease.

Furthermore, the results of this study show that, gut contents analysis may underestimate the impact of a fish species upon mosquito larvae populations, through not accounting for the non-consumptive 
impact of fish upon larvae survival. For example, $G$. occidentalis were found to kill, but not consume mosquito larvae. This contrasts with other species such as G. holbrooki and Pacific blue-eye (Pseudomugil signifer Kner, 1865 Pseudomugilidae), which have been found to reach a level of satiation when exposed to the high prey densities and late instar larvae used in this study (Willems et al., 2005). This previously unreported behaviour of G. occidentalis, combined with their high level of mosquito larvae consumption and ability to tolerate a broad salinity and temperature range, make them a promising candidate for control of mosquito larvae to supplement larviciding efforts as part of an integrated vector control programme.

Some authors have proposed that the incidence and geographic range of mosquito-borne diseases will increase in Australia as a result of climate change (Hales et al., 2002; McMichael et al., 2006). However, other authors have suggested that changes in incidence and geographic range of mosquito-borne diseases are more complex and that climate alone is unlikely to be responsible for the southward spread of mosquitoborne disease. For example, human behaviour associated with our society's response to climate change, such as increased domestic rainwater tanks, and other factors including urban stormwater detention wetlands, international travel and entry of vectors via international vessels may also facilitate the spread of mosquito-borne disease (Russell, 1998; Russell et al., 2009).

Our results show that an additional factor-loss of endemic fish biodiversity-may also increase the spread of mosquito vector populations in southwestern Australia. For example, while once common on the urbanised Swan Coastal Plain G. occidentalis, $N$. vittata and B. porosa now only exist in 20, 9 and $7 \%$, respectively, of water bodies in this region (Hourston et al., 2014). The seasonal drying of some previously permanent waterbodies in south-western Australia due to reduced rainfall as a result of deforestation (Pitman et al., 2004), climate change (CSIRO, 2009), increased groundwater extraction (Balla \& Davis, 1993), and management practices (Davis \& Froend, 1999), has in many cases resulted in the loss of endemic fish populations that naturally consume and control mosquito larvae. This, combined with the propensity to establish artificial urban lakes without consideration for mosquito control by fish or other methods, is likely to contribute to an increase in the incidence and spread of mosquito-borne diseases. Indigenous fish species may therefore be suitable for stocking artificial waterbodies in urban areas and restocking natural waterbodies to both control mosquitoes and conserve biodiversity by establishing satellite repository populations. Conservation repositories are particularly relevant for the critically endangered $G$. truttaceus, which currently has a severely restricted distribution in the extreme south of the state, but is not constrained to this region by temperature.

For endemic fish species to provide a viable alternative to G. holbrooki for mosquito control, it is essential that adequate numbers of fish are available for stocking. In recent years, our research group have developed techniques for the hatchery production of two species of Galaxias ( $G$. occidentalis and $G$. truttaceus) and Western Pygmy perch ( $N$. vittata). Ongoing research in this field will determine whether restocking or periodical replenishment will be required in order to use these fish for mosquito control.

In Western Australia, G. occidentalis and $G$. truttaceus survive in a wide temperature range $\left(<28^{\circ} \mathrm{C}\right)$ and occur in fresh to saline water (0-15 ppt). They belong to the family Galaxiidae, a southern hemisphere, circum-temperate family (McDowall, 2010), that clearly warrants further investigation as a biological control agent for mosquito populations in Australia, New Zealand, South America and Madagascar. Elsewhere in the world where Galaxiidae do not occur naturally, it is likely that other small-bodied endemic fish species have evolved to occupy a similar ecological niche. Our results indicate that if these endemic fish populations have declined or been replaced by $G$. holbrooki, the loss of this biodiversity may contribute to an increase in the transmission of mosquito-borne disease. Further research at both a country and regional scale, to identify and where necessary replenish, these endemic fishes for mosquito control may have benefits for both aquatic biodiversity and human health.

Acknowledgments For advice on identification and culture of mosquito larvae the authors would like to thank Dr Michael Lindsay, (Department of Health, Western Australia) and Jay Nicholson and Cheryl A. Johansen, (Arbovirus Surveillance and Research Laboratory, The University of Western Australia). The authors wish to thank Dr Brett Molony, Dr Michael Snow, Dr Cecile Dang (Department of Fisheries Western Australia), Dr 
Phil Vercoe (The University of Western Australia) and Dr Brian Jones (Aquatic Animal Health Ministry for Primary Industries, New Zealand) for reviewing this manuscript.

Open Access This article is distributed under the terms of the Creative Commons Attribution 4.0 International License (http:// creativecommons.org/licenses/by/4.0/), which permits unrestricted use, distribution, and reproduction in any medium, provided you give appropriate credit to the original author(s) and the source, provide a link to the Creative Commons license, and indicate if changes were made.

\section{References}

Abbott, W. S., 1925. A method of computing the effectiveness of an insecticide. Journal of Economic Entomology 18: 265-267.

Balla, S. A. \& J. A. Davis, 1993. Wetlands of the Swan Coastal Plain Volume 5: managing Perth's wetlands to conserve the aquatic fauna. Water Authority of Western Australia, Balcatta.

Blaustein, L., 1992. Larvivorous fishes fail to control mosquitoes in experimental rice plots. Hydrobiologia 232: 219-232.

Brown, C. J. \& A. C. Fox, 1966. Mosquito Fish (Gambusia affinis) in a Montana Pond. Copeia 1966: 614-616.

Cech, J. J., M. J. Massingill, B. Vondracek \& A. L. Linden, 1985. Respiratory metabolism of mosquitofish, Gambusia affinis effects of temperature, dissolved oxygen, and sex difference. Environmental Biology of Fishes 13: 297-307.

Courtenay, W. R. J. \& G. K. Meffe, 1989. Small fishes in strange places: a review of introduced poeciliids. In Meffe, G. K. \& F. F. Snelson (eds), Ecology and evolution of livebearing fishes (Poeciliidae). Prentice-Hall Inc., New Jersey: 319-332.

Coutant, C. C., 1977. Compilation of temperature preference data. Journal of the Fisheries Research Board of Canada 34: 739-745.

Coy, N. J., 1979. Freshwater fishing in south-west Australia. Jabiru Books, Perth.

CSIRO, 2009. Surface water yields in south-west Western Australia. A report to the Australian Government from the CSIRO South-West Western Australia Sustainable Yields Project. CSIRO Water for a Healthy Country Flagship, Australia.

Davis, J. A. \& R. Froend, 1999. Loss and degradation of wetlands in southwestern Australia: underlying causes, consequences and solutions. Wetlands Ecology and Management 7: 13-23.

Gill, H. S., S. J. Hambleton \& D. L. Morgan, 1999. Is the Mosquitofish, Gambusia holbrooki (Poeciliidae), a major threat to the native freshwater fishes of south-western Australia? 5th Indo-Pacific Fish Conference, 3-8 November 1997, Noumea, New Caledonia: 79-87.

Hales, S., N. de Wet, J. Maindonald \& A. Woodward, 2002. Potential effect of population and climate changes on global distribution of dengue fever: an empirical model. Lancet 360: 830-834.
Homski, D., M. Goren \& A. Gasith, 1994. Comparative evaluation of the larvivorous fish Gambusia affinis and Aphanius dispar as mosquito control agents. Hydrobiologia 284: 137-146.

Hourston, M., J. Ledger, P. Vercoe \& C. Lawrence, 2014. Native and non-native fishes in wetlands of the Swan Coastal Plain, Western Australia. Journal of the Royal Society of Western Australia 97: 331-342.

Hurst, T. P., M. D. Brown \& B. H. Kay, 2004. Laboratory evaluation of the predation efficacy of native Australian fish on Culex annulirostris (Diptera:Culicidae). Journal of the American Mosquito Control Association 20: 286-291.

Lloyd, L. N., 1990. Ecological interactions of Gambusia holbrooki with Australian native fishes. In Pollard, D. A. (ed.), Introduced and Translocated Fishes and Their Ecological Effect. Australian Government Publishing Service, Canberra: 94-97.

Lloyd, L. N. \& J. F. Tomasov, 1985. Taxonomic status of the mosquitofish Gambusia affinis (Poeciliidae), in Australia. Australian Journal of Marine and Freshwater Research 36: 447-451.

Macdonald, J. \& Z. Tonkin, 2008. A review of the impact of eastern gambusia on native fishes of the Murray-Darling Basin. Arthur Rylah Institute for Environmental Research, Department of Sustainability and Environment, Heidelberg.

Mackenzie, J. S., M. D. Lindsay, R. J. Coelen, A. K. Broom, R. A. Hall \& D. W. Smith, 1994. Arboviruses causing human disease in the Australasian zoogeographic region. Archives of Virology 136: 447-467.

Major, J., 2009. Native fish fauna in Perth wetlands are declining with increasing wetland degradation. Honours Thesis, School of Animal Biology, The University of Western Australia, Australia.

McDonald, G. \& G. A. Buchanan, 1981. The mosquito and predatory insect fauna inhabiting fresh-water ponds, with particular reference to Culex annulirostris Skttse (Diptera: Culicidae). Australian Journal of EcoIogy 6: 21-27.

McDowall, R. M., 2010. New Zealand Freshwater Fishes: An Historical And Ecological Biogeography. Kluwer Academic Publishers, Netherlands.

McMichael, A. J., R. E. Woodruff \& S. Hales, 2006. Climate change and human health: present and future risks. Lancet 367: 859-869.

Mees, G. M., 1977. Status of Gambusia affinis (Baird \& Girard) in South-Western Australia. Records of the Western Australian Museum 6: 27-31.

Melden, A. B., 1951. Preliminary observations on the effects of temperature and light upon reproduction in Gambusia affinis. Copeia 1951: 148-152.

Morgan, D. L., H. S. Gill \& I. C. Potter, 1998. Distribution, identification and biology of freshwater fishes in southwestern Australia. Records of the Western Australian Museum Supplement No. 56.

Myers, G. S., 1965. Gambusia, the fish destroyer. The Australian Zoologist 13: 102.

Pen, L. J. \& I. C. Potter, 1991. Reproduction, growth and diet of Gambusia holbrooki (Girard) in a temperate Australian river. Aquatic Conservation: Marine and Freshwater Ecosystems 1: 159-172.

Pitman, A. J., G. T. Narisma, R. A. Pielke \& N. J. Holbrook, 2004. Impact of land cover change on the climate of 
southwest Western Australia. Journal of Geophysical Research: Atmospheres 109: 1-12.

Rowe, D. K., J. P. Smith \& C. Baker, 2007. Agonistic interactions between Gambusia affinis and Galaxias maculatus: implications for whitebait fisheries in New Zealand rivers. Journal of Applied Ichthyology 23: 668-674.

Russell, B. M., J. Wang, Y. Williams, M. N. Hearnden \& B. H. Kay, 2001. Laboratory evaluation of two native fishes from tropical north Queensland as biological control agents of subterranean Aedes aegypti. Journal of the American Mosquito Control Association 17: 124-126.

Russell, R. C., 1998. Mosquito-borne arboviruses in Australia: the current scene and implications of climate change for human health. International Journal for Parasitology 28: 955-969.

Russell, R. C., 2002. Ross river virus: ecology and distribution. Annual Review of Entomology 47: 1-31.
Russell, R. C., B. J. Currie, M. D. Lindsay, J. S. Mackenzie, S. A. Ritchie \& P. I. Whelan, 2009. Dengue and climate change in Australia: predictions for the future should incorporate knowledge from the past. Medical Journal of Australia 190: 265-268.

Sokolov, N. P. \& M. A. Chvaliova, 1936. Nutrition of Gambusia affinis on the rice fields of Turkestan. Journal of Animal Ecology 5: 390-395.

Willems, K. J., C. E. Webb \& R. C. Russell, 2005. A comparison of mosquito predation by the fish Pseudomugil signifier Kner and Gambusia holbrooki (Girard) in laboratory trials. Journal of Vector Ecology 30: 87-90.

Wurtsbaugh, W. A. \& J. J. Cech, 1983. Growth and activity of juvenile mosquitofish: temperature and ration effects. Transactions of the American Fisheries Society 112: 653-660. 